\title{
Analysis of the Influence about Uncertain Sound Velocity on the Positioning of Seafloor Control Points
}

\author{
Zhao Chong ${ }^{1}$ and Sun Wenzhou ${ }^{2 *}$ \\ ${ }^{1}$ Xian Survying and Mapping Center, China \\ ${ }^{2}$ Department of Military Oceanography and Hydrography and Cartography, Dalian Naval Academy, China
}

Submission: February 15, 2019; Published: March 25, 2019

Corresponding author: Sun Wenzhou, Department of Military Oceanography and Hydrography and Cartography, Dalian Naval Academy, Dalian, China

\begin{abstract}
The method of determining the coordinates of seafloor control network is introduced. The change law of the sound velocity profile and the influence of this change on ranging error are analyzed, finally, summarizes the problems existing in the determination of the seafloor control
\end{abstract} network.

Keywords: Seafloor control network; Sound velocity profile; Ray-tracing algorithm; Sailing circle

\section{Introduction}

The seafloor control network is one of the important parts of the marine geodetic datum, which can help to exploit marine resources and marine science research. Firstly, hydrographic surveying and charting requires high-precision and high reliability supporting marine geodetic datum. The construction of the seafloor control network will be one of the effective methods for extending the geodetic datum form land to marine. Secondly, all marine engineering and human underwater activities are depending on navigation and positioning service, and the seafloor control network has the most high-precision in the all methods. Finally, the seafloor control network is also the basic supporting facility for researching marine geology, marine organism and marine environment.

\section{Method for Determining Coordinates of seafloor cont- rol network}

The key of the seafloor control network construction is to achieve the cm-level seafloor control points positioning [1]. For now, the mainly method is GNSS combined with acoustic ranging [26], GNSS can provide 3-d coordinate for survey ships [7]. Acoustic devices can get the slant range from transducer installed under the survey ship to transponder on the seafloor [8]. After multiple measurements, using intersection positioning model can get the absolute coordinate of the seafloor control points. The current method for single control point coordinate determines usually by sailing circle, which means that survey ship sails the circle with transponder on the seafloor as its center and water depth as its radius. This method can get the exact horizontal coordinate of control point. However, the precision is mostly limited by the influence of upper sea sound velocity profile changing, and the separately measuring method can cause low production efficiency. As the transponder function of measuring mutually the distance between each other widely used, the base line between seafloor control points can be measured by this method. Because of stabilization of sound velocity profile under sea, the base line measurement between seafloor control points has better precision. Besides, the pressure transducer in the transponder can provide depth with better precision. Based on whole measured data, the unknown coordinate can be determined by network adjustment, which makes fast calculating all 3-d coordinates come true.

\section{The influence of temporal and spatial variation of sound velocity on ranging error}

The uncertainty of sound velocity profile is the main effect on underwater acoustic measure precision. The equivalent ranging error can be divided into two parts: one is caused by the measuring inaccuracy of background sound velocity profile. The other is periodic error caused by internal waves, tide and temperature change during a day. First, the solar radiation causes periodic change of surface water temperature. Surface water heat has affected a certain depth of seawater through heat conduction. The temperature change causes periodic change of sound velocity profile. Internal waves led the water to move vertically which makes heat exchange between the upper and lower water and causes periodic change of sound velocity profile.

The calculation of slant ranges from transducer installed under the survey ship to transponder on the seafloor is based on 
ray-tracing algorithm. The sound velocity profile which based on ray-tracing algorithm is measured. The instantaneous sound velocity profile is changing over time. So, the difference between this will cause ranging error which is the main error resource of acoustic range. Based on ST law, the error include fixture (caused by background sound velocity profile error) and period (caused by sound velocity profile change over time). The fixture has a linear relationship with the slant range. The period of periodic error is like the period of sound velocity profile area change.

\section{Major Difficulties in Seafloor Control Points Positioning}

The transition from absolute datum of water surface to underwater is based on survey ship. The trajectory of the survey ship determines that the observation points can only be distributed on the sea surface. So that one of the problems is the seafloor control point absolute positioning with low vertical accuracy. Traditional method believes the sound velocity is more stable and changing less above the seafloor. So, the transponder measuring mutually the distance between each other has high precision. However, truth is not like that. The bottom of sea temperature still changes significantly [9]. If the base line extends to few kilometers, whether the gradient change of sound velocity in horizontal direction can be ignored or not? That causes a new problem: how can we calculate the base line between the control points? It is not useful for the method directly based on ray-tracing algorithm any more. The key to solve the two problems is sound velocity. Therefore, we can see the key point of achieving high-precision seafloor control network still is the sound velocity correction.

\section{Discussion}

Among the current studies of seafloor control network, the traditional research is complete and systematical. However, subjecting to the influence of backward measure equipment and imperfect data processing methods, the accuracy of control point positioning is very poor. Spiess, et al. [2] do not emphasize its role in control datum. They use this method as an important way to monitor the movement of Submarine plate and the crustal defor- mation. The research guides the method of data processing. They pay more attention to the change of the control point relative position in the geodetic coordinate system. In fact, the error characteristic of underwater acoustic ranging is in favor of realizing this research goal. The real problem is if the transponder is existing as marine geodetic datum, we should focus on not only the exact relative position of control point, but also the absolute coordinate in the geodetic coordinate system. It makes the construction of the seafloor control points become a challenging task.

\section{References}

1. YANG Yuanxi, XU Tianhe, XUE Shuqiang (2017) Progresses and Prospects in Developing Marine Geodetic Datum and Marine Navigation of China. Acta Geodaetica et Cartographica Sinica 46(1): 1-8.

2. Spiess F N, Chadwell C D, Hildebrand J A (1998) Precise GPS/Acoustic positioning of seafloor reference points for tectonic studies. Physics of the Earth \& Planetary Interiors 108(2): 101-112.

3. Fujita M, Ishikawa T, Mochizuki M (2006) GPS/Acoustic seafloor geodetic observation: method of data analysis and its application. Earth Planets \& Space 58(3): 265-275.

4. Kussat N H, Chadwell C D, Zimmerman R (2005) Absolute positioning of an autonomous underwater vehicle using GPS and acoustic measurements. IEEE Journal of Oceanic Engineering 30(1): 153-164.

5. Matsumoto Y, Fujita M (2006) Combined GPS/Acoustic Seafloor Geodetic Observation System by Japan Coast Guard. J geod soc japan 52(4): 273-283.

6. Gagnon K, Chadwell C D, Norabuena E (2005) Measuring the onset of locking in the Peru-Chile trench with GPS and acoustic measurements. Nature 434(7030): 205-208.

7. Watanabe S I, Ishikawa T, Yokota Y (2015) Non-volcanic crustal movements of the northernmost Philippine Sea plate detected by the GPS-acoustic seafloor positioning. Earth Planets \& Space 67(1): 184193.

8. Spiess F N (1985) Suboceanic Geodetic Measurements. IEEE Transactions on Geoscience \& Remote Sensing ge-23(4): 502-510.

9. Zhao Jianhu, Zou Yajing, Zhang Hongmei (2016) A new method for absolute datum transfer in seafloor control network measurement. Journal of Marine Science \& Technology 21(2): 216-226.

\section{Your next submission with Juniper Publishers will reach you the below assets}

- Quality Editorial service

- Swift Peer Review

- Reprints availability

- E-prints Service

- Manuscript Podcast for convenient understanding

- Global attainment for your research

- Manuscript accessibility in different formats

( Pdf, E-pub, Full Text, Audio)

- Unceasing customer service

Track the below URL for one-step submission https://juniperpublishers.com/online-submission.php 